Article

\title{
Pattern and Causes of Oral and Maxillofacial Injuries Presented to a Tertiary Care Public Dental Hospital in Strictly Imposed COVID-19 Lockdown Scenario
}

\author{
Gayan Surendra ${ }^{1, *(\mathbb{D}, \text { Irosha Perera }}{ }^{2}$, Anura Ranasinghe ${ }^{3}$, Vindya Kumarapeli ${ }^{4}$, \\ Rachel Tham ${ }^{5}$ and Pujitha Wickramaratne ${ }^{6}$ \\ 1 Office of Deputy Director, National Dental Hospital (Teaching) Sri Lanka, Colombo 00700, Sri Lanka \\ 2 Preventive Oral Health Unit, National Dental Hospital (Teaching) Sri Lanka, Colombo 00700, Sri Lanka; \\ irosha666rukmali@gmail.com \\ 3 Oral \& Maxillofacial Unit C, National Dental Hospital (Teaching) Sri Lanka, Colombo 00700, Sri Lanka; \\ anura.raanasinghe@gmail.com \\ 4 Bureau of Non-Communicable Diseases, Ministry of Health, Nutrition \& Indigenous Medicine, Sri Lanka, \\ Colombo 01000, Sri Lanka; vindyalk@yahoo.com \\ 5 Mary Mackillop Institute for Health Research, Australian Catholic University, \\ Melbourne, VIC 3000, Australia; rachel.tham@acu.edu.au \\ 6 Restorative Dentistry Unit B, National Dental Hospital (Teaching) Sri Lanka, Colombo 00700, Sri Lanka; \\ wajirapani@gmail.com \\ * Correspondence: gayansuren@gmail.com; Tel.: +94-713-402-185
}

Received: 15 October 2020; Accepted: 20 November 2020; Published: 24 November 2020

\begin{abstract}
The unprecedented COVID-19 pandemic has indelibly impacted routine healthcare provision across the globe. Nevertheless, management of traumatic injuries has remained a priority patient care service of oral and maxillofacial (OMF) practice. This study aimed to explore the pattern and mechanisms of OMF injuries presenting at a major public dental hospital during a COVID-19 lockdown period in Sri Lanka. An enhanced OMF injury surveillance system was established at the National Dental Hospital (Teaching) Sri Lanka (NDHTSL) on 1 March 2020. OMF injury surveillance data from 1 March 2020 to 31 May 2020 were collated from the "enhanced injury surveillance form". This period overlapped with the strictly imposed island-wide COVID-19 community lockdown. Pre-COVID-19 period (November 2017 to January 2020) OMF injury data were compared with this period. OMF injuries were categorized as hard tissue, extra-oral or intra-oral soft tissue, upper and middle face fractures and mandibular fractures. Data were analyzed with descriptive statistics, Fisher's exact and Chi-square tests of significance. A total of $361 \mathrm{OMF}$ injuries were identified among 208 patients who were predominantly males $(71.6 \%)$; mean age was $24.95 \pm 2.76$ years. Injuries to gingivae and oral mucosa (26.9\%) were the leading type, followed by extra-oral soft tissues $(22.1 \%)$, periodontal injuries $(20.7 \%)$ and hard tissue injuries (20.2\%). Upper face and mandibular fractures accounted for $2.9 \%$ and $1.9 \%$, respectively. Most patients sustained their injuries due to falls at their homes and surrounds. This was significantly increased compared to the pre-COVID-19 period $(p=0.0001)$. The significant increase in OMF injuries associated with falls around the home during the COVID-19 lockdown scenario in Sri Lanka compared to the pre-COVID-19 period may need further investigation in order to understand the how these injuries may be prevented.
\end{abstract}

Keywords: COVID-19; falls; home; lockdown; oral and maxillofacial 


\section{Introduction}

The COVID-19 pandemic, the unprecedented global public health emergency caused by the SARS-CoV-2 virus, has indelibly impacted healthcare systems, economies and societies across the globe [1]. Healthcare systems have evolved to manage the impact of this pandemic by transforming into prioritized emergency healthcare services at the expense of ongoing and routine care services. Triaging and patient risk stratification combined with adherence to meticulous infection control procedures have become cornerstones in this context [2-4]. Dentistry clinical settings inherently carry a high risk of transmission of droplet and aerosol-borne infections, such as COVID-19, due to a range of factors [4]. Firstly, oral healthcare providers operate in close proximity to the patient's face, eyes and nose, which increases the risk of viral transmission via saliva (oral secretions) and respiratory secretions (speaking, sneezing, coughing, etc.) [5-8]. Secondly, clinical treatments which use high-speed hand-pieces and ultrasonic scalers generate copious small droplets, also known as aerosolized droplet nuclei or aerosols. These aerosols are able to remain suspended in the air for prolonged periods and may be inhaled by people working beyond the immediate clinical treatment zone [4-8]. Consequently, physical distancing (staying apart by at least $1 \mathrm{~m}$ ) and meticulous use of personal protective equipment and infection control protocols in oral healthcare provision have become pivotal to contain the disease and control its transmission [8,9]. An array of evidence-based protocols has been developed for the prevention and control of COVID-19 infection within dental practice which have been adopted by many countries [10-12]. Workflows, based on the firsthand experiences of countries that reported high burden of the infection, such as Italy, have been developed for dental patient triage, patient and staff entrance into the dental clinic, dental treatment and post-treatment management $[13,14]$.

Exclusive emergency care provision adopted by healthcare services was aimed at minimizing hospital and clinical encounters during lockdown periods which were imposed for containment of community spread of the COVID-19 virus [15]. Consequently, routine and elective surgical procedures were cancelled and deferred until transmission rates were stabilized and the reproductive rate $\left(R_{0}\right)$ of the COVID-19 virus was demonstrated to be below one $[8,16]$. The majority of healthcare facilities, including intensive care units, and healthcare staff were primarily deployed for COVID-19 care provision over less urgent healthcare demands [15]. Such a scenario has revolutionized the landscape of oral and maxillofacial (OMF) surgical practice, driven by moral and ethical imperatives $[5,10]$. A worldwide survey of OMF surgical practice has revealed that from 20 March to 12 April 2020, there was a $66 \%$ reduction in OMF services delivered in the majority of participating centers. There was marked heterogeneity in relation to these reductions across and within countries during this period that overlaid the first peak of the COVID-19 pandemic [17]. Nevertheless, management of traumatic injuries remained one of the most maintained services, accounting for $82 \%$ of OMF services provided [17]. Moreover, dental trauma such as avulsion, luxation and complicated crown fractures with pulpal involvement has been prioritized as needing emergency treatment despite the COVID-19 crisis [8].

Compared to other pandemics, such as Severe Acute Respiratory Syndrome (SARS) in February 2003 and Middle East Respiratory Syndrome (MERS) in 2012, COVID-19 remains a persisting and rapidly evolving global public health threat. New waves of infections are emerging with rising morbidity and mortality [18], irrespective of whether containment of the infection has been achieved previously. Therefore, COVID-19-induced health system transformations need evidence-based decision-making based on country-specific, updated baseline data. Despite being a unique catastrophe, sustained provision of emergency health care services for patients during the ongoing COVID-19 pandemic and its subsequent waves, indicates the need for continuing resilience in health care services under extremely challenging and demanding contexts $[19,20]$. Furthermore, lockdown scenarios which include restrictions to local travel and transport underpinned by "stay home-stay safe" approaches may have unintended benefits or consequences for some types of OMF trauma. As such, the patterns and trends of OMF injuries as a result of COVID-19 lockdown restrictions merit careful examination, 
analysis and understanding in order to plan necessary interventions for appropriate and effective healthcare delivery.

The first case of COVID-19 community transmission in Sri Lanka was reported on 11 March 2020. One of the unique features of Sri Lanka's response to the COVID-19 pandemic was its stringent enforcement of community lockdown: closure of schools, public and private offices; introducing work from home strategies; social/physical distancing; closure of supermarkets, retail shops; and imposing a country-wide quarantine curfew. This resulted in curtailing indigenous community transmission of the infection and limiting the death toll to 13 as for 24 September 2020, attributed to COVID-19 [16]. In Sri Lanka, oral healthcare provision has been closely integrated into the existing public healthcare delivery model, which follows a hierarchical delivery structure of levels of care [21]. Accordingly, in line with clinical practice restrictions around the world [4-9], providing routine dental treatment which involved aerosol-generating procedures was temporarily suspended. However, like many other countries, essential oral cancer and OMF trauma retained priority care status [22-25] in Sri Lanka. Hence, all OMF injury cases who presented to the Emergency Treatment Unit (ETU) of National Dental Hospital (Teaching) Sri Lanka (NDHTSL), which is the country's premier, multispecialty tertiary care public dental hospital, were treated.

Against this backdrop, the aim of the present study was to explore the pattern and mechanisms of OMF injuries experienced in a major city presented to NDHTSL during a stringent lockdown period in a lower middle-income country, Sri Lanka. This paper describes the impact of COVID-19 community lockdown on OMF injuries and healthcare provision in the country, which is characterized by an efficient pro-poor public healthcare delivery model.

\section{Experimental Section}

The NDHTSL adhered to the guidelines issued by the Ministry of Health and professional Dental Colleges and transformed its scope and context of patient care services during the community lockdown period. Accordingly, routine dental treatment was deferred and temporarily halted and service provision was limited to emergency treatment that included attending to OMF injuries.

A strengthened OMF injury surveillance system was introduced to NDHTSL from 1 March 2020, which was deemed to be a longstanding need. Accordingly, a comprehensive OMF injury data collection form was developed by triangulation of findings from an extensive literature review and contributions from local and international OMF traumatology and injury surveillance experts. The form was refined to be concise and user-friendly by a consultative expert panel comprised of specialists in OMF surgery, restorative dentistry, orthodontics and dental public health. It was pre-tested and validated at the NDHTSL outpatient dental clinic. The form obtained personal and socio-demographic data, epidemiological information—date and time of injury, geographic location, mechanism of injury, place of occurrence, etc.-and details regarding the extent and severity as well as department of management. OMF injuries were categorized into dental injuries involving injuries to the hard dental tissues and pulp, injuries to the periodontal tissues, injuries to the supporting bone and injuries to gingiva or oral mucosa, extra-oral soft tissue, upper and middle face fractures and mandibular fractures. Dental trauma was classified based on the classification developed by Andreasen, 1981 [26], and adapted to the local context with the expert panel.

The data collection forms were kept at ETU, Restorative Dentistry units and OMF Surgery units of NDHTSL, where patients presented with OMF injuries. Data were gathered centrally by the Planning Unit, which is a routine process for data entry, analysis and dissemination. This current analysis includes OMF injury surveillance data collated over the period 1 March to 31 May 2020. This time period overlapped with the stringently imposed COVID-19 lockdown scenario in Sri Lanka.

For comparative purposes, pre-COVID OMF injury data were extracted from the previously used data collection form for the period of November 2017 to January 2020. However, it did not have data pertaining to detailed dental and facial injuries as the prevailed injury surveillance system used only the umbrella term of "OMF injuries" to capture the whole spectrum of injuries. 
The data were entered and analyzed using SPSS-21 software package. Descriptive statistics were used and groups were compared using Fisher's exact and Chi-square tests of statistical significance. Ethics approval was obtained from Ethics Review Committee, Faculty of Medicine, Colombo (EC/20/005).

\section{Results}

During the study period, a total of 361 OMF injuries were identified among 208 patients predominantly residing in the Colombo city and its suburbs. Males dominated (71.6\%) in the sample, with the mean age of 24.95 (95\% CI: 22.19-27.97) years. Of these, $82.4 \%$ were among $11-20$-year-old adolescents, $79.5 \%$ were among preschool children aged up to 5 years and another $77.8 \%$ belonged to children aged 6-10 years. However, among 21-40-year and $41-60$-year-old adults, $68.9 \%$ and $62.5 \%$ were males. Moreover, among elderly participants aged above 60 years, both genders seemed at risk of sustaining OMF injuries, with slight female preponderance (Table 1).

Table 1. Distribution of Oral \& Maxillofacial injury patients by age group and gender.

\begin{tabular}{cccccccc}
\hline & \multicolumn{7}{c}{ Age Categories (in Years) } \\
\cline { 2 - 7 } Gender & $\mathbf{0 - 5}$ & $\mathbf{6 - 1 0}$ & $\mathbf{1 1 - 2 0}$ & $\mathbf{2 1 - 4 0}$ & $\mathbf{4 1 - 6 0}$ & $\mathbf{> 6 0}$ & Total Number \\
& $\mathbf{n ( \% )}$ & $\mathbf{n ( \% )}$ & $\mathbf{n ( \% )}$ & $\mathbf{n}(\mathbf{\%})$ & $\mathbf{n}(\mathbf{\%})$ & $\mathbf{n}(\mathbf{\%})$ & in Each Gender (\%) \\
\hline Male & $31(79.5)$ & $28(77.8)$ & $28(82.4)$ & $31(68.9)$ & $25(62.5)$ & $6(42.9)$ & $149(100.0)$ \\
Female & $8(21.5)$ & $8(21.2)$ & $6(27.6)$ & $15(32.1)$ & $15(47.5)$ & $8(57.1)$ & $59(100.0)$ \\
Total & $39(18.7)$ & $36(17.3)$ & $34(16.3)$ & $45(19.2)$ & $40(19.2)$ & $14(6.8)$ & $208(100.0)$ \\
\hline
\end{tabular}

According to the percentage distribution of OMF injuries by type over the given period, injuries to gingivae and oral mucosa (26.9\%) were the leading type, followed by extra-oral soft tissues $(22.1 \%)$, periodontal injuries $(20.7 \%)$ and dental hard tissue injuries $(20.2 \%)$. In contrast, the relative proportions of injuries to supporting bone (5.3\%) upper face and mandibular fractures were low, such as $2.9 \%$ and $1.9 \%$, respectively. As for healthcare provision, $50.5 \%$ of injured patients were exclusively treated at the ETU of NDHTSL and subsequently discharged, while another $22.1 \%$ and $13.5 \%$ were initially managed at ETU and referred to restorative and OMF units, respectively. Moreover, $6.3 \%$ of injured patients were referred from the ETU to OMF units for necessary management.

As illustrated in Table 2, the majority of all types of OMF injuries were caused by falls. Occupational injuries were as low as $0.3 \%$. Other less common causes were sporting injuries, assault and being hit by an object, although this may overlap with sporting injuries and assault. However, for all types of injuries, the relative contribution of road traffic accidents was considerably less $(14.1 \%)$ compared to falls $(68.0 \%)$.

As illustrated in Table 3, the majority of OMF injuries occurred at home or near the home compared to other places of occurrence.

Falls were the dominant mechanism of injury over other mechanisms among all age groups. Moreover, home and area surrounding home were the leading places of occurrence of injuries compared to other places across all age groups. Those differences in contribution of falls compared to other mechanisms of injuries and place of occurrence were statistically significant $(p=0.0001)$ (Table 4$)$.

We tested the distribution of mechanism of OMF injury by gender. There was no significant difference in injuries caused by falls compared to other causes by gender $(p=0.119)$ (Table 5$)$.

As demonstrated in Table 6, there was a total of 142 patients who sustained OMF injuries due to falls among 204 patients. Of these, $76.0 \%$ had fallen at home. Moreover, $66.7 \%$ of "hit by an object injuries" and $61.5 \%$ of violence/assault inflicted injuries had occurred at home. 
Table 2. Distribution of oral and maxillofacial injuries by mechanism.

\begin{tabular}{|c|c|c|c|c|c|c|c|c|}
\hline Mechanism & $\begin{array}{c}\text { Dental Hard } \\
\text { Tissues and } \\
\text { Pulp } \\
\text { n (\%) }\end{array}$ & $\begin{array}{c}\text { Injury to } \\
\text { Periodontal } \\
\text { Tissues } \\
\text { n (\%) }\end{array}$ & $\begin{array}{l}\text { Injury to } \\
\text { Supporting } \\
\text { Bones } \\
\text { n (\%) }\end{array}$ & $\begin{array}{c}\text { Injury to } \\
\text { Gingivae and } \\
\text { Oral Mucosa } \\
\text { n (\%) }\end{array}$ & $\begin{array}{l}\text { Extra-Oral Soft } \\
\text { Tissues } \\
\text { n (\%) }\end{array}$ & $\begin{array}{c}\text { Upper and } \\
\text { Middle Face } \\
\text { n (\%) }\end{array}$ & $\begin{array}{l}\text { Mandibular } \\
\text { n (\%) }\end{array}$ & $\begin{array}{c}\text { Total Number of Each } \\
\text { Cause of Injury } \\
\text { n (\%) }\end{array}$ \\
\hline Fall & $56(74.7)$ & 54 (70.1) & $15(75.0)$ & $68(67.3)$ & $51(71.8)$ & $6(60.0)$ & $5(71.4)$ & $255(70.3)$ \\
\hline $\mathrm{RTA}^{1}$ & $8(10.6)$ & $9(11.7)$ & $2(10.0)$ & 12 (11.9) & $18(25.3)$ & $3(30.0)$ & $1(14.3)$ & $53(14.6)$ \\
\hline Violence/assault & $3(4.0)$ & $5(6.5)$ & $0(0.0)$ & $7(6.9)$ & $2(0.02)$ & $1(10.0)$ & $1(14.3)$ & $19(5.2)$ \\
\hline Sport injury & $4(5.3)$ & $3(3.9)$ & $2(10.0)$ & $6(5.9)$ & $0(0.0)$ & $0(0.0)$ & $0(0.0)$ & $15(4.1)$ \\
\hline Hit by an object & $3(4.0)$ & $3(3.9)$ & $0(0.0)$ & $4(3.9)$ & $0(0.0)$ & $0(0.0)$ & $0(0.0)$ & $10(2.7)$ \\
\hline Self-inflicted & $1(1.3)$ & $2(2.6)$ & $1(5.0)$ & $2(2.0)$ & $0(0.0)$ & $0(0.0)$ & $0(0.0)$ & $6(1.6)$ \\
\hline Animal attack & $0(0.0)$ & $0(0.0)$ & $0(0.0)$ & $2(2.0)$ & $0(0.0)$ & $0(0.0)$ & $0(0.0)$ & $2(0.5)$ \\
\hline Occupational & $0(0.0)$ & $1(1.3)$ & $0(0.0)$ & $0(0.0)$ & $0(0.0)$ & $0(0.0)$ & $0(0.0)$ & $1(0.3)$ \\
\hline Total & $75(100.0)$ & 77 (100.0) & $20(100.0)$ & $101(100.0)$ & $71(100.0)$ & $10(100.0)$ & $7(100.0)$ & $361(100.0)$ \\
\hline
\end{tabular}

Table 3. Distribution of OMF injuries by place of occurrence.

\begin{tabular}{|c|c|c|c|c|c|c|c|c|}
\hline $\begin{array}{c}\text { Place of } \\
\text { Occurrence }\end{array}$ & $\begin{array}{c}\text { Dental Hard } \\
\text { Tissues and } \\
\text { Pulp } \\
\text { n (\%) }\end{array}$ & $\begin{array}{l}\text { Injury to } \\
\text { Periodontal } \\
\text { Tissues } \\
\text { n (\%) }\end{array}$ & $\begin{array}{l}\text { Injury to } \\
\text { Supporting } \\
\text { Bones } \\
\text { n (\%) } \\
\end{array}$ & $\begin{array}{c}\text { Injury to } \\
\text { Gingivae and } \\
\text { Oral Mucosa } \\
\text { n (\%) }\end{array}$ & $\begin{array}{l}\text { Extra-Oral Soft } \\
\text { Tissues } \\
\text { n (\%) }\end{array}$ & $\begin{array}{c}\text { Upper and } \\
\text { Middle Face } \\
\text { n (\%) }\end{array}$ & $\begin{array}{c}\text { Mandibular } \\
\text { n (\%) }\end{array}$ & $\begin{array}{c}\text { Total Number of Each } \\
\text { Location of Injury } \\
\text { n ( } \%)\end{array}$ \\
\hline Home/residence & $44(64.7)$ & $45(66.2)$ & $11(64.7)$ & $66(76.7)$ & $45(69.2)$ & $5(83.3)$ & $2(33.3)$ & $218(69.0)$ \\
\hline Road & 13 (19.1) & $8(11.8)$ & $0(0.0)$ & $8(9.3)$ & $8(12.3)$ & $1(16.7)$ & $2(33.3)$ & 40 (12.6) \\
\hline Educational & $8(11.8)$ & $11(16.2)$ & $4(23.5)$ & $7(8.1)$ & $6(9.2)$ & $0(0.0)$ & $0(0.0)$ & $36(11.4)$ \\
\hline Working place & $2(2.9)$ & $4(5.9)$ & $2(11.8)$ & $4(4.7)$ & $5(7.7)$ & $0(0.0)$ & $2(33.3)$ & $19(6.1)$ \\
\hline Playground & $1(1.5)$ & $0(0.0)$ & $0(0.0)$ & $1(1.2)$ & $1(1.5)$ & $0(0.0)$ & $0(0.0)$ & $3(0.9)$ \\
\hline Total & $68(100)$ & $68(100)$ & $17(100)$ & $86(100)$ & $65(100)$ & $6(100)$ & $6(100)$ & $316(100.0)$ \\
\hline
\end{tabular}


Table 4. Distribution of mechanism of injury and place of occurrence by age group.

\begin{tabular}{|c|c|c|c|c|c|c|c|}
\hline & \multicolumn{6}{|c|}{ Age Categories } & \\
\hline & $0-5$ Years & 6-10 Years & 11-20 Years & 21-40 Years & 41-60 Years & $>60$ Years & \\
\hline \multicolumn{8}{|c|}{ Mechanism } \\
\hline Fall & $39(100.0)$ & $31(86.1)$ & $19(55.9)$ & $24(53.3)$ & $20(50.0)$ & $9(64.3)$ & \\
\hline Other & $0(0.0)$ & $5(13.9)$ & $15(45.1)$ & $21(46.7)$ & $20(50.0)$ & $5(35.7)$ & $p=0.000$ \\
\hline Total & $39(100.0)$ & $36(100.0)$ & $34(100.0)$ & $45(100.0)$ & $40(100.0)$ & $14(100.0)$ & \\
\hline \multicolumn{8}{|c|}{ Place of Occurrence } \\
\hline Home and surroundings & $39(100.0)$ & $26(72.2)$ & $23(67.6)$ & $26(57.8)$ & $28(70.0)$ & $13(92.9)$ & \\
\hline Other & $0(0.0)$ & $10(27.8)$ & $11(32.4)$ & $19(42.2)$ & $12(30.0)$ & $1(7.1)$ & $p=0.000$ \\
\hline Total & $39(100.0)$ & $36(100.0)$ & $34(100.0)$ & $45(100.0)$ & $40(100.0)$ & $14(100.0)$ & \\
\hline
\end{tabular}

Table 5. Distribution of mechanism of injury by gender.

\begin{tabular}{ccccc}
\hline \multicolumn{5}{c}{ Mechanism of Injury } \\
\hline \multirow{2}{*}{ Gender } & $\begin{array}{c}\text { Fall } \\
\mathbf{n}(\%)\end{array}$ & $\begin{array}{c}\text { Other } \\
\mathbf{n}(\%)\end{array}$ & $\begin{array}{l}\text { Total } \\
\mathbf{n}(\%)\end{array}$ \\
\hline Male & $97(65.1)$ & $52(34.9)$ & $149(100.0)$ & \\
Female & $45(76.3)$ & $14(23.7)$ & $59(100.0)$ & $p=0.119 *$ \\
\hline \multicolumn{5}{c}{${ }^{*}$ Chi-square test. }
\end{tabular}

Table 6. Distribution of mechanism of injury by place of occurrence.

\begin{tabular}{|c|c|c|c|c|c|c|c|}
\hline \multirow{2}{*}{ Mechanism } & \multicolumn{6}{|c|}{ Place } & \multirow[b]{2}{*}{$\begin{array}{c}\text { Total Number of Injured } \\
\text { Patients by Given Mechanism } \\
n(\%)\end{array}$} \\
\hline & $\begin{array}{c}\text { At Home/Residence } \\
\mathrm{n}(\%)\end{array}$ & $\begin{array}{l}\text { At Working Place } \\
n(\%)\end{array}$ & $\begin{array}{l}\text { At Educational } \\
\text { Institute } \\
\text { n (\%) }\end{array}$ & $\begin{array}{c}\text { Near the Home } \\
\text { n (\%) }\end{array}$ & $\begin{array}{l}\text { At Road } \\
\mathrm{n}(\%)\end{array}$ & $\begin{array}{l}\text { At Ground } \\
\text { n (\%) }\end{array}$ & \\
\hline RTA $^{1}$ & $0(0.0)$ & $0(0.0)$ & $0(0.0)$ & $11(42.3)$ & $15(57.7)$ & $0(0.0)$ & $26(100.0)$ \\
\hline Sport injury & $0(0.0)$ & $0(0.0)$ & $3(33.3)$ & $4(44.4)$ & $0(0.0)$ & $2(22.2)$ & $9(100.0)$ \\
\hline Occupational & $0(0.0)$ & $1(100.0)$ & $0(0.0)$ & $0(0.0)$ & $0(0.0)$ & $0(0.0)$ & $1(100.0)$ \\
\hline Fall & $108(76.1)$ & $5(3.5)$ & $10(7.0)$ & $9(6.4)$ & $10(7.0)$ & $0(0.0)$ & $142(100.0)$ \\
\hline Violence/assault & 8 (61.5) & $0(0.0)$ & $0(0.0)$ & $2(15.4)$ & $3(23.1)$ & $0(0.0)$ & $13(100.0)$ \\
\hline Self-inflicted & $1(50.0)$ & $0(0.0)$ & $1(50.0)$ & $0(0.0)$ & $0(0.0)$ & $0(0.0)$ & $2(100.0)$ \\
\hline Animal attack & $0(0.0)$ & $0(0.0)$ & $0(0.0)$ & $2(100.0)$ & $0(0.0)$ & $0(0.0)$ & $2(100.0)$ \\
\hline \multirow[t]{2}{*}{ Hit by an object } & $6(66.7)$ & $2(22.2)$ & $0(0.0)$ & $0(0.0)$ & 1 (11.1) & $0(0.0)$ & $9(100.0)$ \\
\hline & & & & & & Total & 204 \\
\hline
\end{tabular}

${ }^{1}$ Road traffic accident. 
As presented in Table 7, the majority (82.4\%) of OMF injuries caused by "falls" had occurred at home and its surroundings, compared to $17.6 \%$ of OMF injuries caused by the same mechanism which occurred at other places and those differences were statistically significant $(p=0.0001)$.

Table 7. Significance of mechanism of injury by place of occurrence.

\begin{tabular}{ccccc}
\hline $\begin{array}{c}\text { Mechanism of } \\
\text { Injury }\end{array}$ & $\begin{array}{c}\text { Home \& Surrounding } \\
\mathbf{n}(\mathbf{\%})\end{array}$ & $\begin{array}{c}\text { Other Places } \\
\mathbf{n ~ ( \% )}\end{array}$ & $\begin{array}{c}\text { Total } \\
\mathbf{n}(\mathbf{\%})\end{array}$ & \\
\hline Fall & $117(82.4)$ & $25(17.6)$ & $142(100.0)$ & \\
Other & $38(57.6)$ & $28(42.4)$ & $66(100.0)$ & $p=0.000^{*}$ \\
\hline
\end{tabular}

Table 8 shows that there was a significant increase in OMF injuries associated with falls during the COVID-19 lockdown compared to the pre-COVID-19 era for the period of November 2017 to January 2020. However, we could only compare some of the surveillance data in this regard, such as reported cause of injury, but there was limited information on any of the new data items, such as detailed categorization of OMF injuries which were used with the "enhanced" OMF injury surveillance data form.

Table 8. Comparison of mechanism of OMF injury by pre-COVID-19 and COVID-19 lockdown scenario.

\begin{tabular}{ccccc}
\hline Mechanism & Pre-COVID-19 $^{* *}$ & COVID-19 Lockdown & Total & \\
\hline Fall & $90(51.7)$ & $142(68.2)$ & 232 & \\
Other mechanism & $84(48.3)$ & $66(41.8)$ & 150 & \\
Total & $174(100.0)$ & $208(100.0)$ & $382(100.0)$ & $p=0.001^{*}$ \\
\hline \multicolumn{5}{c}{}
\end{tabular}

\section{Discussion}

The COVID-19 pandemic reached a peak during July 2020, yet the reported global daily incidence continued to increase with rising numbers of cases and deaths [19]. Hence, countries across the globe need to critically consider alternative models of healthcare provision to cater to the prioritized needs of patients. Furthermore, emerging research evidence has revealed the massive influence of the COVID-19 pandemic on the use of emergency dental services at a tertiary care public dental hospital in Beijing, China during the COVID-19 epidemic [27]. Lessons learnt by such endeavors allow for the transformation of policy into practice in order to manage the scarce resources of healthcare systems grappling with the burden of COVID-19. Within this unique setting, the current study illustrated the spectrum and causes of OMF injuries that presented to a multispecialty tertiary care public dental hospital in Sri Lanka during the stringently imposed COVID-19 lockdown.

As revealed by the current findings, the OMF injury patients presented with a spectrum of injuries involving dental hard tissues and pulp, periodontal tissue, supporting bone, gingivae/oral mucosa, extra-oral tissues, upper and middle face and mandibular injuries of varying magnitude. Dental injuries involving hard and soft tissues as well as extra-oral soft tissues were prominent in comparison to mid-facial and mandibular fractures. The most common injury type of the present study was injury to gingivae and oral mucosa $(26.9 \%)$, in contrast to periodontal tissue injuries $(51.8 \%)$ in a study on traumatic dental injuries in a teaching hospital in Wuhan, China while under transmission control measures during the COVID-19 epidemic between 23 January and 7 April 2020 [23]. The findings of both studies are comparable as they used the same dental trauma classification of Andreason [26]. Moreover, the findings of the present study revealed that the majority of patients $(82.4 \%)$ had sustained injuries due to falls which had occurred at their homes and its surroundings. Not surprisingly, the majority of road traffic accidents and sport injuries had occurred in close proximity to homes, which could be attributable to the scenario of travel restrictions during the COVID-19 community lockdown. 
The extensive literature on dental trauma confirms that falls were among the dominant causes for OMF injuries sustained at home, especially among children and adolescents [28]. The high prevalence of traumatic dental injuries among preschool children aged 0-6 years is considered to be a public health problem [29]. Furthermore, studies have reported that falls were the main etiology and home/residence was the most common place of occurrence of injuries among preschool children [30]. A recent study found that malocclusion characteristics were associated with less severe enamel trauma, whereas socioeconomic and home environment characteristics were influential in more severe dentin/pulp trauma [31]. Therefore, it could be speculated that the COVID-19 lockdown scenario could have mediated the occurrence of traumatic dental injuries among preschool children through such factors.

The most salient finding that emerged from the present study was the significant increase in falls that caused OMF trauma during the COVID-19 lockdown compared to the pre-COVID-19 era (November 2017 to January 2020) from $51.7 \%$ to $68.2 \%$. These findings corroborate the findings from Wuhan, where falls contributed to $89 \%$ of OMF injuries in the COVID-19 era compared to $35.0 \%$ in the pre-COVID-19 era [23]. The mean age of 24.95 years of injured patients of the present study was comparable to the mean age of 21.6 years of the Wuhan study, representing economically productive age groups in both countries. Furthermore, males were more likely to sustain OMF injuries than females, with a ratio of 2.5:1 both in pre-COVID-19 and COVID-19 lockdown scenarios in our study. In contrast, in Wuhan, in both periods, the male:female ratio was 1.5 to 1 [23]. The differences in male:female ratios in sustaining OMF injuries in two countries merit further investigation but could be attributed to gender-based sociocultural differences in exposure to risk of such injuries in the two countries.

Therefore, the current findings indicate that the COVID-19 lockdown was underpinned by the adoption of the "stay home, stay safe" approach; however, this may have contributed to the higher incidence of OMF injuries at home in Sri Lanka. Accordingly, patients across all age groups, from toddlers to older adults, experienced falls at their homes and sustained OMF injuries. Moreover, there was only one patient who suffered from occupational injury during this period which was attributable to the lockdown that led to the temporarily closure of workplaces. Further, during this period, there was a decline in vehicular and passenger transport, leading to a decline in Road Traffic Accident (RTA) [20], currently deemed the leading cause of injuries and hospitalization in Sri Lanka [32-34]. OMF trauma attributed to RTA was among the top treatment priorities encountered by the majority of OMF units in public hospitals across the country [33]. This phenomenon of the declining incidence of OMF injuries attributed to RTA reported by other countries during COVID-19 travel restrictions $[35,36]$ was substantiated by these findings. Furthermore, the relatively low proportions of upper and mid-facial as well as mandibular fractures, associated with high-impact forces, compared to other types of OMF injuries further supported the less frequent occurrence of RTA-induced OMF injuries during this COVID-19 lockdown period. Even though the "stay home-stay safe" approach rendered protection against COVID-19 infection transmission, it may not have been protective for OMF injuries due to falls. There could be country- and culture-specific trends and patterns of health issues including OMF injuries in COVID-19 lockdown scenarios across the globe that merit further exploration. For example, the increased incidence of mental health issues among various age groups is an emerging finding within this context $[37,38]$. However, in contrast to current findings, one study from the UK reported that domestic violence and abuse (DVA) were among the predominant causes of dental/OMF trauma, which could be attributable to the household isolation measures of the COVID-19 pandemic [34]. The present study did not obtain enough in-depth data to identify whether DVA was a significant contributing factor to the OMF injuries presented. Nevertheless, as revealed by the findings, $61.5 \%$ of patients suffered from injuries due to violence/assault encountered at their homes. Therefore, complying with the authors' recommendations, careful exploration of DVA among patients seeking dental traumatology services [39] would be of emerging importance for Sri Lanka as well. 
The patients who attended the leading public dental hospital in Sri Lanka with OMF injuries demonstrated a pattern of falls that occurred at their homes and the areas surrounding their homes across all age groups. Further in-depth investigation as to the nature of these falls is required to understand which factors may be addressed through awareness-raising and prevention programs, particularly during community lockdown periods. The Sri Lankan experience of exacerbation of DVA during this period requires further investigation. Furthermore, country-specific strategies are needed to prevent OMF trauma in heterogeneous COVID-19 lockdown scenarios across the globe. As dental trauma dominated injury patterns across all age groups, which involved both primary and permanent teeth, their management is deemed to be a priority amidst the COVID-19 pandemic scenario across the global practice $[8,38,40]$. However, it is not clear whether there was an overall change in emergency dental visits attributable to dental trauma during the COVID-19 lockdown period compared to the pre-COVID-19 era. One study reported that there was a reduction in dental trauma-based emergency visits from $14.2 \%$ to $10.5 \%$ during the COVID-19 epidemic [27].

This study adds value to the limited literature on OMF injuries during the COVID-19 pandemic. It has the strength of having data with high coverage $(72 \%)$, accuracy $(100 \%)$ and timeliness $(100 \%)$ pertaining to OMF injury surveillance. As specialized and general dental care provision is being integrated into the existing public healthcare delivery model in the country, services are provided free of charge at the point of service delivery. Therefore, people encountering OMF injuries could access emergency services from a network of public hospitals as well as from private hospitals providing dental care. However, the present findings should be interpreted cautiously as the OMF injury data were limited only to NDHTSL. Nevertheless, this center is the leading public dental hospital catering to a larger proportion of the population in the capital city, Colombo; retrospective analysis of such data has helped clinicians and health policymakers to identify characteristic patterns in OMF trauma during the COVID-19 lockdown scenario. As there was significant increase in falls during this period, thus corroborating the findings of the study conducted in Wuhan under transmission control measures during the COVID-19 epidemic, it would be important to raise public awareness through appropriate strategies. In the absence of a national injury prevention and control program in place in Sri Lanka, despite its public health significance, there is an emerging demand for initiating such a program. Therefore, injury prevention and control should be incorporated into primary healthcare services as a component of the essential health services package.

\section{Conclusions}

Our findings corroborated existing findings but presented novel insights into dental traumatology during a strictly imposed COVID-19 lockdown scenario in Sri Lanka, a country that was able to successfully control the community spread of COVID-19. The "stay home-stay safe" strategy that was pertinent for physical distancing and isolation to curtail the community spread of COVID-19 infection may have exacerbated the existing trend of falls. Hence, public awareness should be raised in this regard by appropriate strategies. Current findings and their implications could have translational value for other countries within similar contexts. Further research is warranted with a larger cross-section of the community to strengthen the level of evidence to support these recommendations.

Author Contributions: Conceptualization, G.S.; Data curation, G.S. and I.P.; Formal analysis, G.S. and I.P.; Investigation, G.S. and I.P.; Methodology, G.S. and I.P.; Project administration, G.S.; Resources, A.R. and P.W.; Software, G.S. and I.P.; Supervision, I.P. and V.K.; Validation, I.P. and V.K.; Writing-original draft, G.S. and I.P.; Writing-review and editing, R.T. All authors have read and agreed to the published version of the manuscript.

Funding: This research received no external funding.

Acknowledgments: Authors wish to acknowledge the contribution of health staff of participating units of National Dental Hospital (Teaching) Sri Lanka.

Conflicts of Interest: The authors declare no conflict of interest. 


\section{References}

1. Valencia, D.N. Brief Review on COVID-19: The 2020 Pandemic Caused by SARS-CoV-2. Cureus 2020, 12, e7386. [CrossRef] [PubMed]

2. Wong, E.L.-Y.; Yeoh, E.-K.; Dong, D. Covid-19: Transforming healthcare will require collaboration and innovative policies. BMJ 2020, 369. [CrossRef] [PubMed]

3. Dadashzadeh, A.; Alamdari, N.G.; Ala, A.; Dehghannejad, J.; Jabbarzadeh, F.; Babaie, N. Triage guidelines for emergency department patients with COVID-19. J. Res. Clin. Med. 2020, 8, 12. [CrossRef]

4. Meng, L.; Hua, F.; Bian, Z. Coronavirus Disease 2019 (COVID-19): Emerging and Future Challenges for Dental and Oral Medicine. J. Dent. Res. 2020, 99, 481-487. [CrossRef]

5. Lee, Y.-L.; Chu, D.; Chou, S.-Y.; Hu, H.-Y.; Huang, S.-J.; Yen, Y.-F. Dental care and infection-control procedures during the COVID-19 pandemic: The experience in Taipei City Hospital, Taiwan. J. Dent. Sci. 2020. [CrossRef]

6. Ge, Z.-Y.; Yang, L.-M.; Xia, J.-J.; Fu, X.-H.; Zhang, Y.-Z. Possible aerosol transmission of COVID-19 and special precautions in dentistry. J. Zhejiang Univ. Sci. B 2020, 21, 361-368. [CrossRef]

7. Blackhall, K.; Downie, I.; Ramchandani, P.; Kusanale, A.; Walsh, S.; Srinivasan, B.; Shields, H.; Brennan, P.; Singh, R.P. Provision of Emergency Maxillofacial Service During the COVID-19 Pandemic: A Collaborative Five Centre UK Study. Br. J. Oral Maxillofac. Surg. 2020, 58, 698-703. [CrossRef]

8. Ayub, K.; Alani, A. Acute endodontic and dental trauma provision during the COVID-19 crisis. Br. Dent. J. 2020, 229, 169-175. [CrossRef]

9. Jamal, M.; Shah, M.; Almarzooqi, S.H.; Aber, H.; Khawaja, S.; El Abed, R.; Alkhatib, Z.; Samaranayake, L.P. Overview of transnational recommendations for COVID-19 transmission control in dental care settings. Oral Dis. 2020. [CrossRef]

10. American Dental Association Official Website. What Constitutes a Dental Emergency? Available online: https://success.ada.org/ \{\}/media/CPS/Files/Open\%20Files/ADA_COVID19_Dental_ Emergency_DDS.pdf (accessed on 20 July 2020).

11. American Dental Association ADA. Interim Guidance for Management of Emergency and Urgent Dental Care. Updated 4 January 2020. Available online: https://www.ada.org/ \{\}/media/CPS/Files/COVID/ADA_ Int_Guidance_Mgmt_Emerg-Urg_Dental_COVID19?utm_source=adaorg\&utm_medium=VanityURL\& utm_content=interimguidance-flowcharts\&utm_campaign=covid-19 (accessed on 20 April 2020).

12. National Health Service Official Website. COVID-19 Guidance and Standard Operating Procedure. Urgent Dental Care Systems in the Context of Coronavirus. Version 1. 2020. Available online: https:/www.england.nhs.uk/coronavirus/wp-content/uploads/sites/52/2020/04/C0282covid-19-urgent-dental-care-sop.pdf (accessed on 20 April 2020).

13. Izzetti, R.; Nisi, M.; Gabriele, M.; Graziani, F. COVID-19 Transmission in Dental Practice: Brief Review of Preventive Measures in Italy. J. Dent. Res. 2020, 99, 1030-1038. [CrossRef]

14. Peditto, M.; Scapellato, S.; Marcianò, A.; Costa, P.; Oteri, G. Dentistry during the COVID-19 Epidemic: An Italian Workflow for the Management of Dental Practice. Int. J. Environ. Res. Public Health 2020, 17, 3325. [CrossRef] [PubMed]

15. Ellis, R.; Hay-David, A.; Brennan, P. Operating during the COVID-19 pandemic: How to reduce medical error. Br. J. Oral Maxillofac. Surg. 2020, 58, 577-580. [CrossRef] [PubMed]

16. Barca, I.; Cordaro, R.; Kallaverja, E.; Ferragina, F.; Cristofaro, M.G. Management in oral and maxillofacial surgery during the COVID-19 pandemic: Our experience. Br. J. Oral Maxillofac. Surg. 2020, 58, 687-691. [CrossRef] [PubMed]

17. Maffia, F.; Fontanari, M.; Vellone, V.; Cascone, P.; Mercuri, L. Impact of COVID-19 on maxillofacial surgery practice: A worldwide survey. Int. J. Oral Maxillofac. Surg. 2020, 49, 827-835. [CrossRef]

18. Strzelecki, A. The second worldwide wave of interest in coronavirus since the COVID-19 outbreaks in South Korea, Italy and Iran: A Google Trends study. Brain Behav. Immun. 2020, 88, 950-951. [CrossRef]

19. Legido-Quigley, H.; Mateos-García, J.T.; Campos, V.R.; Gea-Sánchez, M.; Muntaner, C.; McKee, M. The resilience of the Spanish health system against the COVID-19 pandemic. Lancet Public Health 2020, 5, e251-e252. [CrossRef]

20. Balkhair, A.A. COVID-19 Pandemic: A New Chapter in the History of Infectious Diseases. Oman Med. J. 2020, 35, e123. [CrossRef] 
21. Ratnasekera, N.; Perera, I.; Kandapolaarachchige, P.; Surendra, G.; Dantanarayana, A. Supportive care for oral cancer survivors in COVID-19 lockdown. Psycho-Oncology 2020, 29, 1409-1411. [CrossRef]

22. Ministry of Healthcare and Nutrition. National Oral Health Survey Sri Lanka 2015-2016; Ministry of Healthcare and Nutrition: Colombo, Sri Lanka, 2018.

23. Yang, Y.; Zhang, W.; Xie, L.; Li, Z.; Li, Z. Characteristic changes of traumatic dental injuries in a teaching hospital of Wuhan under transmission control measures during the COVID-19 epidemic. Dent. Traumatol. 2020, 36, 584-589. [CrossRef]

24. Ren, Y.-F.; Rasubala, L.; Malmstrom, H.; Eliav, E. Dental Care and Oral Health under the Clouds of COVID-19. JDR Clin. Transl. Res. 2020, 5, 202-210. [CrossRef]

25. Jayasuriya, N.S.S.; Perera, I.R.; Ratnapreya, S. Re: Maxillofacial Surgery and COVID-19, the Pandemic! J. Maxillofac. Oral Surg. 2020, 19, 475-476. [CrossRef] [PubMed]

26. Andreasen, J.O.; Ahrensburg, S.S. History of the Dental Trauma Guide. Dent. Traumatol. 2012, $28,336-344$. [CrossRef] [PubMed]

27. Guo, H.; Zhou, Y.; Liu, X.; Tan, J. The impact of the COVID-19 epidemic on the utilization of emergency dental services. J. Dent. Sci. 2020. [CrossRef] [PubMed]

28. Azami-Aghdash, S.; Azar, F.E.; Azar, F.P.; Rezapour, A.; Moradi-Joo, M.; Moosavi, A.; Oskouei, S.G. Prevalence, etiology, and types of dental trauma in children and adolescents: Systematic review and meta-analysis. Med. J. Islam. Repub. Iran 2015, 29, 234.

29. Born, C.D.; Jackson, T.H.; Koroluk, L.D.; Divaris, K. Traumatic dental injuries in preschool-age children: Prevalence and risk factors. Clin. Exp. Dent. Res. 2019, 5, 151-159. [CrossRef]

30. Malmgren, B.; Andreasen, J.O.; Flores, M.T.; Robertson, A.; DiAngelis, A.J.; Andersson, L.; Cohenca, N.; Lauridsen, E.; Bourguignon, C.; Hicks, L.; et al. International Association of Dental Traumatology guidelines for the management of traumatic dental injuries: 3. Injuries in the primary dentition. Dent Traumatol. 2012, 28, 174-182. [CrossRef]

31. Bonfadini, I.; Pereira, J.T.; Knorst, J.K.; Luz, P.B.; Scapinello, M.; Hugo, F.N.; De Araujo, F.B.; Hilgert, J.B. Maternal characteristics, home environment, and other factors associated with traumatic dental injuries in preschool children. Dent. Traumatol. 2019, 36, 33-40. [CrossRef]

32. Ministry of Healthcare and Nutrition. Weekly Epidemiological Report; Ministry of Healthcare and Nutrition: Colombo, Sri Lanka, 2010; Volume 37.

33. Wimalaratne, K.; Lee, J.I.; Lee, K.H.; Lee, H.Y.; Lee, J.H.; Kang, I.H. Emergency medical service systems in Sri Lanka: Problems of the past, challenges of the future. Int. J. Emerg. Med. 2017, 10, 10. [CrossRef]

34. Jayasundera, K.S.; Navaratne, G. A Study on The Pattern of Maxillofacial Trauma Due to Motorcycle Accidents and The Influence of Helmets. Sri Lanka Dent. J. 2016, 46, 96-101.

35. Oguzoglu, U. Discussion Paper Series COVID-19 Lockdowns and Decline in Traffic Related Deaths and Injuries; IZA-Institute of Labor Economics: Bonn, Germany, 2020.

36. Aloi, A.; Alonso, B.; Benavente, J.; Cordera, R.; Echániz, E.; González, F.; Ladisa, C.; Lezama-Romanelli, R.; López-Parra, Á.; Mazzei, V.; et al. Effects of the COVID-19 Lockdown on Urban Mobility: Empirical Evidence from the City of Santander (Spain). Sustainability 2020, 12, 3870. [CrossRef]

37. Fegert, J.M.; Vitiello, B.; Plener, P.L.; Clemens, V. Challenges and burden of the Coronavirus 2019 (COVID-19) pandemic for child and adolescent mental health: A narrative review to highlight clinical and research needs in the acute phase and the long return to normality. Child Adolesc. Psychiatry Ment. Health 2020, 14, 1-11. [CrossRef] [PubMed]

38. Galea, S.; Merchant, R.M.; Lurie, N. The Mental Health Consequences of COVID-19 and Physical Distancing the Need for Prevention and Early Intervention. JAMA Intern. Med. 2020, 180, 817-818. [CrossRef] [PubMed] 
39. Coulthard, P.; Hutchison, I.; Bell, J.A.; Coulthard, I.D.; Kennedy, H. COVID-19, domestic violence and abuse, and urgent dental and oral and maxillofacial surgery care. Br. Dent. J. 2020, 228, 923-926. [CrossRef] [PubMed]

40. Day, A.P.; Djemal, S.; Albadri, S. Primary Dentition Acute Management of Traumatic Injuries and Follow-up Care during the COVID-19 Pandemic. 2020. Available online: https://www.researchgate.net/publication/ 341966683 (accessed on 21 June 2020).

Publisher's Note: MDPI stays neutral with regard to jurisdictional claims in published maps and institutional affiliations.

(C) 2020 by the authors. Licensee MDPI, Basel, Switzerland. This article is an open access article distributed under the terms and conditions of the Creative Commons Attribution (CC BY) license (http://creativecommons.org/licenses/by/4.0/). 